\section{Fixation and transport in a postal cytodiagnostic service}

\author{
J. A. HIGGINS and J. P. SMITH From the Depart- \\ ment of Pathology, Christie Hospital, Withington, \\ Manchester 20
}

Perfect preservation of cytoplasmic and nuclear detail is essential in cytology: even transient drying of a smear either before or after fixation is deleterious. This creates a problem for a postal cytodiagnostic service as bottles containing inflammable fixative may not be posted. Various rehydration techniques (Bonime, 1961; Koss and Durfee, 1961) have been tried and found unsatisfactory. Dipping the fixed slide in glycerine (Ayre and Dakin, 1946) is satisfactory but makes handling somewhat unpleasant. The fixative detailed below appears to solve the problem by leaving, after evaporation, a waxy protective film over the smear.

Absolute alcohol ${ }^{1} \ldots \ldots \ldots \ldots .100 \mathrm{ml}$.
Carbowax (1500) $\ldots \ldots \ldots \ldots .0 \mathrm{~g}$.

Glacial acetic acid .........0.2 $\mathrm{ml}$. (to $\mathrm{pH} 5 \cdot 8-6 \cdot 0)$

If the fixative cannot be collected from the laboratory, the carbowax and acetic acid may be dissolved in $5.0 \mathrm{ml}$. of warm distilled water. This small quantity of base material can be sent through the post and the alcohol added by the receiving clinic.

The fixative is applied from a plastic dropping bottle on to the smear immediately it has been made and while it is still wet. The slide is then left on a flat surface, not near heat, for about five or $\mathbf{1 0}$ minutes during which time the alcohol will evaporate and a waxy film will be left over the smear. The slide is put in a 4 in. $\times 1$ in. transparent plastic bag: several of these then go into a wooden postal slide box of conventional pattern. Slides with a ground area at one end are used in this service: the patient's name can be written in pencil on this area for identification purposes.

Over 2,000 smears have been fixed and posted in this way during the past few months with highly satisfactory results. The method is simple and cheap and there is no danger of contamination between slides.

We are indebted to many medical and lay members of the North Western branch of the Family Planning Association for cooperation in developing this technique.

\section{REFERENCES}

Ayre, J. E., and Dakin, E. (1946). Canad. med. Ass. J., 54, 489. Bonime, R. G. (1961). Cancer Cyt., 4, 22.

Koss, L. G., and Durfee, G. R. (1961). Diagnostic Cytology and its Histopathologic Bases, p. 337. Pitman, London.

'Spiritus meth: indust., B.P. may be substituted for absolute alcohol.

Received for publication 12 February 1963

\section{Book Reviews}

THE SCIENTIFIC BASIS OF MEDICINE: ANNUAL REVIEW, 1962. Edited by the British Postgraduate Medical Federation. (Pp. xi + 365; illustrated. 40s.) The Athlone Press, London: University of London. 1962.

A few years ago when I was asked to review a previous volume in the series the Scientific Basis of Medicine, I described it as a series of 'bedtime stories', and I believe this description can still be used for the present annual review of 1962 since each lecture is a 'thriller' and provides much food for thought.

Pathologists in whatever field will find here a series of lectures on a variety of subjects all of which will have a bearing on the future of his department, for research procedures often become the routine investigations of tomorrow. The lectures of Knox, Glynn, Court Brown, Lennox, Pearse, and Kay already suggest that laboratories may have to extend the range of investigations as indicated by these authors, and each clarify some theoretical considerations of each subject. The remaining papers in this edition, with the exception of that of Nabarro and Collier, which is rather more of a clinical nature than the others, have important theoretical implications but are none the worse for that, and certainly suggest a future basis of research.

Perhaps the most satisfying nature of the lecture series is the high standard of editing and the production of the lectures in standard form, which makes all of them satisfying reading. Personally I feel that every pathologist should read these lectures as they will be of value to him as a guide to the future.

E. M. DARMADY

DE INTERCAPILlaire CELLEN VAN DE GLOMERULUS By Paul Michielsen. Foreword by J. Hamburger. (Pp. 243; 43 figures. Belg. fr. 410.) Arscia Brussels: Uitgaven N.V. 1962.

This monograph by Paul Michielsen is written in Dutch with a résumé in French and a short summary in English and is an account of an electron microscopic study of the intercapillary cells of the glomerulus in normal animals and in human pathological material obtained by renal biopsy.

As much of the detailed observations and technique are in Dutch, it may be difficult for all but the multilingual investigator to get the maximum value from this work. Nevertheless it is supported by 23 illustrations and 349 references, and it is obvious that it is a careful appraisal of recent work on electron microscopy of the glomerulus. His investigations suggest to him that intercapillary cells of the glomerulus are not fibroblasts but smooth muscle cells, and supports the concept that the pathological lesion in lobular glomerulonephritis is a massive proliferation of intercapillary cells.

He also believes that the juxtaglomerular apparatus consists of modified smooth muscle cells and the intercapillary cells are peripheral prolongations of the same 
structure, and that 'diverticula' found in the intercapillary lumina are pressoreceptors transmitting information to the juxtaglomerular apparatus.

This work is likely to have a limited appeal to British pathologists unless they are working in the renal field.

E. M. DARMADY

ADRENOCORTICAL DiSORders A Guide to Diagnosis. By

H. Miller and J. A. Durant. (Pp. 70; 14 figures. 15s.)

London: Pitman Medical Publishing Co. 1962.

This short book, written by a pathologist and a biochemist, is designed to help clinicians and pathologists who are not specialists in the subject. After a short summary of the chemistry, metabolism, and pharmacology of the adrenocortical hormones, there is a description of the main biochemical investigations employed to elucidate disorders of the adrenal cortex, followed by accounts of their use in the diagnosis of states of over- and undersecretion by the gland. At the end there is a more detailed account of steroid chemistry and nomenclature.

The book succeeds in giving a clear account of biochemical methods for diagnosing adrenocortical disorders, and should be of considerable value to those for whom it is written. There is little to criticize, except perhaps the recommendation that, in the A.C.T.H. test, 17-ketosteroids as well as 17-hydroxysteroids should be estimated on all three control urines and all three test urines; in most cases a clear-cut answer can be obtained from two 17hydroxycorticosteroid estimations only, one on a representative bulk sample of the control urines and one on the third test urine. Perhaps the next edition could dispense with names such as SU4885 and compound S which are now purely historical, and could omit altogether the Kepler-Robinson-Power test which may be considered obsolete.

The printing is clear and there are few errors. The index is adequate. The binding, though flexible, is strong and the whole fits into the pocket of a white coat. Authors and publishers have done their work well.

$$
\text { G. K. MCGOWAN }
$$

LECTURE NOTES ON PATHOLOGY By A. D. Thomson and R. E. Cotton (Pp. xv + 1040; 39 figures. 55s.) Oxford: Blackwell Scientific Publications. 1962.

This book will be welcomed by the many undergraduate and postgraduate students who seem to appreciate typewritten summaries of lectures ('handouts'). It is an accurate, business-like and well balanced series of notes on pathology - a remarkable accomplishment considering the concise, didactic, and comprehensive approach used by the authors. Paragraph headings and lists are used to full advantage but the almost telegraphic style makes the book unpleasant to read and at times ambiguous. No photographs and only a few line drawings illustrate the text. The most serious criticism of the book is that it makes an interesting subject seem dull; it is left to the teacher and to the books recommended for additional reading to maintain the student's enthusiasm. Perhaps there is something to be said for the view that scientific publications should have some literary merit in addition to clarity and brevity.

R. B. GOUDIF
THE Disposal of the dead, 2nd ed. By C. J. Polson, R. P. Brittain, and T. K. Marshall. (Pp. $\mathrm{x}+356.45 s$.) London: The English Universities Press. 1962.

So many readers will have profited from Polson's vademecum - the only one of its kind-on the 'Disposal of the dead' that it can hardly be necessary to review the work in the ordinary way. This book was popular because it was accurate and up to date, read well, and filled a gap in the $\frac{\bar{\sigma}}{\partial}$ medico-legal literature. It continues to do so, and, after a $\overparen{\Phi}$ first life of 10 years, only needed revision to conform with the constant progress of statute law. Coroners' rules, the Mental Health Act, the Human Tissues Act, and some $\overrightarrow{0}$ new detail in registration necessitated small text amend- $\vec{\overrightarrow{ }}$ ments. Polson writes with a fluent pen and a great interest $\vec{\omega}$ in fundamentally sound and intelligible English. This most valuable book should be within reach of every? pathologist who wishes to be informed on the rights of $\vec{\sigma}$ necropsy, his duties and responsibilities with the dead, $\sigma$ and his authority to pursue a really searching necropsy.

KEITH SIMPSON

CANCER: A GENERAL GUIDE TO RESEARCH AND ITS TREAT- 음 MENT By N. N. Petrov. Translated by A. P. Fletcher; edited by W. J. P. Neish. (Pp. xvi $+387 ; 102$ figures. $\mathcal{S}$ 80s.) Oxford: Pergamon Press. 1963.

The study of tumours has been singled out for particular $\frac{\mathbb{D}}{3}$ attention in the Soviet Union where in 1960 there were no fewer than 1,000 oncological institutes. 'Cancer', a comprehensive survey as seen through Russian eyes, mugt $\vec{\varphi}$ therefore be welcomed. It is on the whole a well-balanceed book ranging from aetiology and experimental work the treatment and prophylaxis of human tumours. Th references are mostly Russian even when the pioneer work was done elsewhere, and there are some exclusively $\overline{\bar{O}}$ Russian sections, e.g., the account of nervous influences in carcinogenesis. On the debit side are the lack of refer- $\mathbb{D}$ ences later than 1957, some conspicuous gaps (chromosomes, for example, are not mentioned), some doubtful statements, e.g., on the role of trauma, and a rather turgid style with many italicized generalizations. In short, the book can only be recommended to those who seek a guide to Russian oncology.

H. F. M. KAY

PRACTICAL SECTION CUTTING AND STAINING, 4th ed. By

E. C. Claydon. (Pp. vii $+198 ; 31$ figures. 20s.) London: $\delta$

J. \& A. Churchill, Ltd. 1962.

The fact that Mr. Claydon's book has run to four 0 editions should really be sufficient guarantee of its value. It is essentially a book for newcomers to the field of histological technology, who will find in it a great deal of what they need. In this respect the section on formulae is $N$ particularly valuable.

In some respects the book is not really up to date. Even $\stackrel{0}{0}$ for beginners in histology it is surely now essential to consider the use of the cryostat for preparing fresh tissue sections.

In most cases I think the methods selected by the author could be considered the best for the purpose but I doubt if Bennholde's Congo red method for amyloid falls into this category.

A. G. EVERSON PEARSE

\section{مَ}

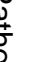

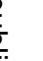

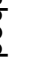
(n) , (n)

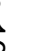

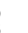

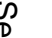

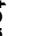

\section{.}

